\title{
Pelatihan Program Terjemah Al-Qur'an Melalui Pendekatan Gramatika Dasar Bahasa Arab
}

\author{
Afridesy Puji Pancarani ${ }^{1}$, Fazlur Rachman ${ }^{2}$ \\ Program Studi Sastra Arab, Fakultas Ilmu Pengetahuan Budaya, Universitas Al Azhar Indonesia, Jl \\ Sisingamangaraja, Kompleks Masjid Agung Al Azhar, Kebayoran Baru, Jakarta Selatan 12110
}

Penulis untuk Korespondensi/E-mail: afridesy@uai.ac.id

\begin{abstract}
Abstrak - Pengabdian kepada Masyrakat berbasis penelitian ini dilaksanakan di Masjid Bahrul Ulum sesuai dengan jadwal yang sudah dibuat oleh isntruktur. Pelatihan ini berjudul, Program Terjemah AlQur'an Al-Huda yang dipelopori oleh Ustadz Ahmad Huseno, S.S. sejak tahun 2003. Kegiatan ini berlangsung dalam kurun waktu kurang lebih delapan bulan sejak bulan Desember 20016 hingga Juli 2017. Teknik pengumpulan data yang dilakukan penulis adalah diawali dengan tahapan observasi ke tempat atau lembaga yang dituju, setelah jelas dan sesuai harapan, dilanjutkan dengan studi lapangan, guna mengetahui segala hal terkait pelatihan Terjemah Al-Qur'an Metode Al-Huda, sehingga dapat ditelusuri kendala dan hambatan yang dihadapi. Setelah itu, barulah penulis melakukan wawancara dengan pelopor atau penemu program ini. Dari kegiatan ini penulis menyimpulkan beberapa hasil yang didapat, yaitu: (1) para peserta dapat memahami kaidah Bahasa Arab dasar; (2) peserta sedikit demi sedikit mulai dapat mempraktekkan terjemah dari beberapa ayat al-Qur'an. Adapun masukan untuk program pelatihan ini adalah harapan terkait pengadaan kamus Indonesia-Arab dan ArabIndonesia dan penjelasan singkat tentang tema ayat-ayat yang akan dibahas.
\end{abstract}

Abstract - The devotion to this research-based society is carried out in the Bahrul Ulum Mosque in accordance with the schedule that has been made by the instructor. This training is entitled translation program AL-Qur'an method AL-Huda pioneered by Ustadz Ahma Huseno, S.S. Since 2003. This Activity taks approximately 8 Months from December 2016 to July 2017.Technique of data collecting by writer is begins with observation to the place or institute referred, after clear and as expected, followed by field study to know all matter related to training of Al-Qur'an translation Al-Huda Method, so can be traced the obstacles Faced. After that, then the author conducted an interview with the pioeer or inventor of this method. After partipating in some activities, author get some inputs to improve this training program. Among them is to provide dictionary and brief explanation of the theme of verses that will be discussed. From this activity the author concludes some of the results obtained, namely: (1) participants can understand basic Arabic rules; (2) participants gradually began to practice the translation of several verses of the Qur'an. The input for this training program is the hope related to the procurement of Indonesian-Arabic and Arabic-Indonesian dictionaries and a brief explanation of the themes of the verses to be discussed.

Keywords - Al- Qur'an, Translation, Arabic

\section{PENDAHULUAN}

Analisis Situasi

Wempelajari dan mendalami ilmu agama IIslam, kini menjadi sebuah kebutuhan masyarakat muslim Indonesia, tua ataupun muda. Dimana dahulu orang-orang yang tertarik untuk belajar agama Islam non formal hanyalah orangorang tua saja. Model belajarnya pun sangat bervariasi. Ada yang memang benar-benar langsung difokuskan ke Al-Qur'an, ada yang belajar dari segi hukum (ilmu fikih), ada juga yang belajar mengaji (belajar cara membaca Al-Qur/an), hingga fokus menghafal Al-qur'an.

Diawali sekitar tahun 2005, terlihat nuansa keislaman masyarakat Indonesia semakin terasa. Hal ini terlihat dari banyaknya kaum muslimin 
(wanita) yang mulai menggunakan hijab (tutup kepala). Terlepas dari hal itu disebabkan adanya paksaan dari orang-orang sekitar, atau memang panggilan jiwa atas hidayah yang Allah berikan. Selain itu, nuansa keislaman ini juga terasa dengan ramainya majlis-majlis ta'lim bukan hanya dengan orang-orang tua, melainkan para remaja Islam juga ikut bergabung dalam kegiatan belajar agama non formal tersebut.

Tidak hanya di masjid-masjid dan majlis ta'lim, hampir di setiap sekolah-sekolah pun memiliki organisasi yang bertujuan mengajak para siswa untuk ikut belajar dan bergabung di komunitas tersebut.

Perlahan, metode belajar komunitas dan majlismajlis tersebut mulai berkembang. Pengajian mereka tidak hanya berkutat pada pemahaman dan penafsiran ayat-ayat suci Al-Qur'an dan hadits, melainkan juga mereka mulai memasukkan unsurunsur ilmu bahasa Arab. Yang mana bahasa Arab merupakan bahasa Al-Qur'an.

\section{Permasalahan}

Dengan munculnnya peminatan dan ketertarikan para umat muslim terhadap ilmu bahasa Arab, maka muncullah sebuah metode pembelajaran AlQur'an yang bertujuan memahami isi Al-Qur'an dari bahasa Arabnya. Metode pembelajaran seperti ini dinamakan PROGRAM TERJEMAH ALQUR'AN AL-HUDA.

Metode ini boleh jadi sudah banyak dilakukan di tempat-tempat lain, namun pada kesempatan kali ini, penulis bermaksud untuk ikut mengabdi dan menelusuri metode yang digunakan oleh Ust. Ahmad Huseno, S.S., selaku pimpinan yayasan sekaligus penemu Metode Terjemah Al-Qur'an AlHuda.

Dalam rangka mewujudkan kerjasama kedua belah pihak yang baik dan sesuai target, maka kami telah merumuskan inti pembahasan dari kegiatan pengabdian kepada masyarakat ini, agar dapat menghasilkan sebuah jawaban praktis sesuai kebutuhan peserta.

Dua rumusan masalah yang ingin dibahas pada penelitian ini, yaitu terkait gagasan baru yang ditemukan pada metode penerjemahan Al-Qur'an yang diterapkan oleh Ust. Ahmad Huseno dalam metode Al-Huda. Penulis juga mendata respon dan hasil yang diperoleh para peserta setelah mengikuti pelatihan penerjemahan $\mathrm{Al}$-Qur'an dengan metode Al-Huda.

\section{Manfaat}

Kegiatan ini dapat bermanfaat bagi :

1. Peserta Majlis (pengajian)

- Mengetahui unsur-unsur bahasa Arab yang terdapat dalam Al-Qur'an, walaupun tidak mendalam.

- Memahami makna yang terkandung dalam Al-Qur'an.

2. Peneliti

- Mengetahui secara detail metode yang digunakan oleh pengajar dan mempraktikannya kepada peserta lain.

- Mengetahui kemampuan peserta khususnya dan masyarakat Indonesia umumnya dalam pemahamannya mengenai ilmu Al-Qur'an.

- Mengetahui aspek-aspek yang dibutuhkan oleh masayarakat Indonesia serta memberikan solusi yang tepat.

\section{Ruang Lingkup}

Pelatihan ini akan bekerja sama dengan seorang Praktisi Bahasa Arab sekaligus penemu metode terjemah Al-Qur'an Al-Huda, Ustadz Ahmad Huseno, S.S. dan dilaksanakan di komplek Masjid Bahrul Ulum Puspiptek, Serpong - Tangerang Selatan.

\section{Data dan Sumber Data}

Adapun bentuk kegiatan 'Program Terjemah AlQur'an ini adalah dilakukan secara rutin 1 minggu $1 \mathrm{x}$ di Masjid Bahrul Ulum, Puspiptek-Serpong, Tangerang Selatan, Banten, dengan ikut bergabung bersama peserta lainnya sekaligus menjadi asisten pengajar.

Dalam kegiatan ini juga, peneliti bermaksud untuk memberikan masukan dan inovasi (jika diperlukan) guna meningkatkan kualitas dan semangat para peserta majlis dalam mempelajari bahasa Arab melalui Al-Qur'an. Oleh karena hal tersebut di atas, maka data dan sumber data akan diperoleh dan diolah langsung berdasarkan praktek yang berlangsung selama masa pelatihan.

\section{LANDASAN TEORI}

Pada bab ini, penulis akan mencoba memberikan informasi singkat mengenai definisi terjemah secara umum dan pengenalan beberapa ilmu dasar 
Bahasa Arab yang pasti ditemukan oleh setiap peserta didik Bahasa Arab.

\section{Terjemah}

Penerjemahan berasal dari Bahasa Arab 'Tarjamah' yang berarti mengalihbahasakan suatu bahasa ke bahasa lain. Sementara menurut KBBI, terjemahan memiliki beberapa arti yang saling berkaitan, diantaranya:

terjemah/ter.je·mah/ $v$, menerjemahkan/me·ner -je.mah $\cdot k a n / v$ menyalin (memindahkan) suatu bahasa ke bahasa lain; mengalihbahasakan (KBBI.web.id/terjemah)

Selain itu, penerjemahan menurut Hoed (23:2006) adalah kegiatan mengalihkan secara tertulis pesan dari teks suatu bahasa (misalnya bahasa Inggris) ke dalam teks bahasa lain (misalnya bahasa Indonesia).

Dalam memahami arti penerjemahan, Catford menekankan bahwa penerjemahan harus beerbasis pada kesepadanan. Penerjemahan menurut Catford (20:1965) merupakan pergantian materi tekstual dari suatu bahasa (BSu) secara sepadan ke dalam bahasa lain (BSa). Tidak hanya ini, perlu diingat bahwa terjemahan yang baik tidak dirasa seperti hasil terjemahan ketika dibaca.

Singkatnya, ada empat kunci yang diperlukan dalam menerjemahkan teks, yakni:

a. Adanya perubahan bentuk (frasa, klausa, kalimat, paragraf dsb.)

b. Penyampaian pesan (yang tidak diubah/ dipertahankan)

c. Kesepadanan (ekuivalensi)

d. Teks terjemahan yang tidak terasa hasil penerjemahan.

Wikipedia menuliskan arti terjemahan sebagai interpretasi dari teks Bahasa sumber untuk menghasilkan teks setara dalam Bahasa target

yang mengkomunikasikan pesan yang sama. Sementara itu menurut beberapa ahli Bahasa terjemahan memiliki makna yang berbeda sesuai dengan konteksnya. Hal ini dikutip dari (http://mae0703.blogspot.co.id/) yang mengatakan, Nida dan Taber memaknai terjemahan (Nida and Taber, 1969:12) sebagai sebuah pesan untuk menghasilkan setara dengan alam terdekat dari pesan Bahasa sumber ke dalam bahasa penerima, pertama dalam hal makna, kedua dalam hal gaya.
Dalam menerjemahkan, penerjemah harus mempertimbangklan beberapa keterbatasan, termasuk konteks, aturan tata Bahasa, menulis konvensi, dan idiom, serta hal-hal lainnya antara dua bahasa. Penerjemah sering tergelincir gaya dan idiom, serta dari Bahasa sumber ke Bahasa sasaran. Sementara itu ilmu terjemahan dimaknai sebagai studi tentang teori dan praktek terjemahan sistematis (jelajah.internet.com).

Dalam sebuah web, digambarkan sebuah skema tentang makna yang berhubungan dengan ilmu terjemehan yang sering kita kenal dengan istilah Visual Artikata, seperti:

\section{Ilmu Dasar Bahasa Arab}

Belajar suatu bahasa tertentu pasti memiliki cara tersendiri. Ada beberapa aturan yang bersifat khusus dan tidak bisa diterapkan secara universal. Aturan itu berkenaan dengan kekhasan bahasa itu sehingga harus mendapatkan perhatian ketika seseorang mulai mempelajari bahasa itu. Hal ini juga berlaku bagi siapa saja yang belajar Bahasa Arab. Di sisi lain, Bahasa Arab akan selalu menjadikan Al-Qurán sebagai acuan utamanya dalam pentapan kaidah-kaidah Bahasa Arab.

Dikutip dari www.kaaffah.xyz/belajar-bahasaarab/, bahasa Arab dalam kaitannya dengan bahasabahasa lain, ia memiliki karakteristik khusus yang tidak dimiliki oleh bahasa lainnya, yaitu:

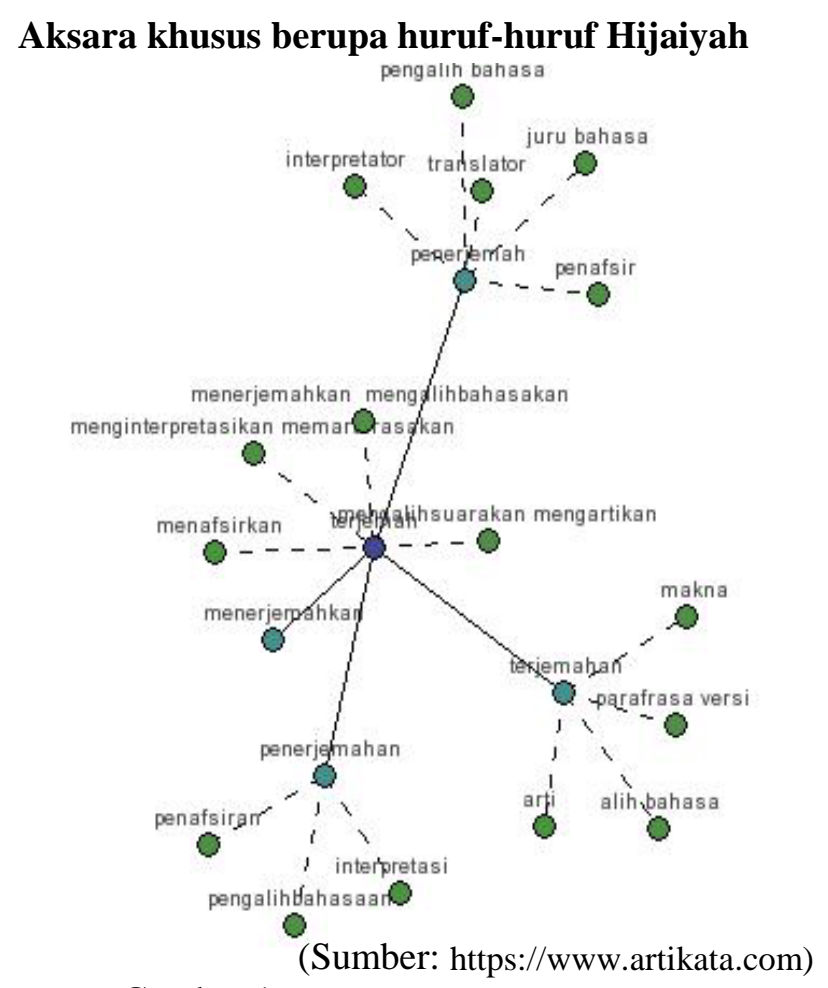

Gambar 1. Visual Artikata “Terjemahan” 
Aksara adalah jenis sistem tanda grafis tertentu atau sistem tanda grafis yg digunakan manusia untuk berkomunikasi dan sedikit banyaknya mewakili ujaran. Aksara Arab adalah aksara yg mula-mula digunakan untuk menuliskan bahasa Arab, diturunkan dari Aramea, ditulis dari kanan ke kiri.

Untuk belajar bahasa Arab tulis, seorang yang belajar bahasa ini harus tahu lebih dulu bagaimana bunyi ujaran dituliskan ke dalam aksara Arab dan sebaliknya bagaimana aksara Arab dibunyikan dalam ujaran.

Aksara Arab terdiri dari 28 huruf (29 jika hamzah dianggap sebagai huruf tersendiri) yang dikenal sebagai huruf-huruf Hijaiyyah. Tiga huruf di antaranya: alif, waw, dan ya' digunakan sebagai vocal panjang (seperti $a a, i i, u u$ ), sebagai diftong atau bunyi rangkap (seperti $a i, a u$ ), dan juga sebagai konsonan lemah.

Apabila bahasa Arab dituliskan dalam aksara Latin, maka yang sebenarnya ditulis adalah bunyinya atau pelafalannya melalui metode transliterasi.

\section{Bahasa Arab Memiliki Panjang dan Pendek} Belajar bahasa Arab adalah belajar bagaimana pelafalan panjang dan pendek suatu kata sangatlah berbeda, karena perbedaan panjang dan pendek ini akan mempengaruhi arti. Dalam bahasa Indonesia pengucapan panjang dan pendek tidak mempengaruhi arti secara mendasar, meskipun kadang-kadang masih bisa berpengaruh dalam tekanan secara lisan.

\section{Jenis Kata Berdasarkan Tashrif}

Bahasa Arab membagi jenis kata menjadi tiga kelompok besar, yaitu: kata kerja, kata benda, dan huruf.

\section{Kata Kerja dan Kata Benda}

Pembentukan kata kerja dan kata benda pada umumnya dilakukan dengan menggunakan wazan tertentu yang diterapkan pada satu akar kata. Wazan adalah rumus atau pola atau timbangan atau bentuk asal yang baku. Akar kata adalah gabungan beberapa huruf Arab yang menjadi dasar perubahan menjadi kata baru dengan makna yang baru setelah diberikan afiks atau imbuhan tertentu. Akar kata paling umum terdiri dari tiga huruf (tsulatsiy). Ada juga yang mengandung empat huruf (ruba'iy), namun jumlahnya jauh lebih sedikit sedikit.

Pembentukan kata kerja dan kata benda ini dalam bahasa Arab dikenal sebagai tashrif dan dipelajari dalam ilmu bahasa Arab khusus yang dikenal sebagai ilmu shorof atau ilmu tashrif. Tashrif menurut bahasa artinya berubah. Sebagai istilah dalam Linguistik, tashrif dikenal sebagai konjugasi. Tashrif atau konjugasi adalah sistem perubahan bentuk kata kerja (verba) atau kata benda (nomina) yang berhubungan dengan jumlah, jenis kelamin, modus, dan waktu. Oleh karena itu, ilmu tashrif juga bisa diartikan sebagai ilmu yang mempelajari tentang perubahan kata dari satu kata dasar menjadi beberapa kata jadian. Tashrif ada dua macam, yaitu tashrif ushul (perubahan asal, pokok, atau dasar) dan tashrif far `i (perubahan cabang).

\section{METODE PELAKSANAAN}

\section{Metode}

Metode yang digunakan dalam kegiatan pengabdian kepada masyarakat yang berbasis penelitian ini memiliki dua tahapan. Tahap pertama yang dilakukan untuk memperoleh data-data pada pelatihan Terjemah Al-Qur'an AL-Huda adalah studi kasus (lapangan). Dimana peneliti berfungsi sebagai pengamat langsung yang memperhatikan secara rinci langkah demi langkah kegiatan pelatihan ini berlangsung, sehingga dapat menghasilkan sebuah kesimpulan yang dapat dijadikan input dan output bagi lembaga yang dikelola oleh Ust. Ahmad Huseno.

Tahapan selanjutnya adalah metode drill application, yaitu metode interaksi aktif antara peserta dengan tim instruktur/pengajar bahasa dengan menyampaikan materi secara tematik sesuai dengan kurikulum yang telah disusun, kemudian mengaplikasannya dalam proses membaca $\mathrm{Al}$ Qur'an.

Kedua tahapan di atas membutuhkan bahan ajar berupa buku referensi dan media-media penguat dalam pembelajaran bahasa Arab dasar, baik audio maupun visual, agar dapat mempermudah proses pemahaman peserta. Selain itu, tersedianya AlQur'an terjemahan dalam pelatihan ini, sangat membantu peserta khususnya dalam rangka memastikan atau meyakinkan kebenaran dari yang telah diterjemahkan.

\section{Tempat dan Waktu}

Kegiatan pengabdian kepada masyarakat berbasis penelitian ini telah dilaksanakan selama 8 bulan, sejak bulan Desember 2016-Juli 2017. Berlokasi di 
Masjid Bahrul Ulum, Perumahan Puspiptek, Serpong-Tangerang Selatan.

Walaupun kegiatan ini tidak hanya bertempat di Masjid Bahrul Ulum saja, namun sesuai kesepakatan antara peneliti dengan tim pelatihan, kegiatan ini akan sepenuhnya dilaksanakan di Masjid Bahrul Ulum Puspiptek, Serpong. Media yang digunakan adalah Al-Qur'an, buku panduan, kamus bahasa Arab, papan tulis, spidol, LCD proyektor, in focus sebagai sarana dan alat bantu saat pelatihan berlangsung.

\section{Teknik Pengumpulan Data}

Dalam memperoleh data pada pengabdian kepada masyarakat berbasis penelitian ini, tidak hanya bergantung kepada satu data (observasi) saja, melainkan membutuhkan beberapa data sebagai penguat dan pelengkap pada tahap pelaporan. Maka dapat disimpulkan, bahwa proses penelitian ini bergantung kepada data primer dan data sekunder. Data primer yang dimaksud adalam observasi pada saat pelatihan berlangsung. Salah satu cara observasi yang dilakukan adalah merekam seluruh kegiatan dari awal sampai akhir, yang videonya akan dijadikan acuan dalam penelitian ini, baik dari segi teknis palatihan, maupun praktis. Adapun datadata sekunder pada pelatihan ini diperoleh dari karya penemu metode Terjemah Al-Qur'an AlHuda yang berjudul 60 Hari Bisa Menerjemahkan Al-Qur'an Sendiri -Panduan Belajar Bahasa Arab Metode Al-Huda-. Data sekunder ini dijadikan sebagai penguat dan landasan teori yang digunakan pada pelatihan ini.

Adapun teknik pengumpulan data penelitian ini diperoleh dengan melalui beberapa tahapan, yaitu :

1. Observasi

Observasi dalam kegiatan ini berupa pengamatan secara langsung terhadap kegiatan yang dilakukan dan menitikberatkan kepada dua hal ini, yaitu : pemberian materi oleh intstruktur dan pemahaman yang diterima peserta.

\section{Studi Pustaka}

Studi pustaka ini dilakukan guna memperoleh materi secara lengkap dan urutan-urutannya secara beraturan. Studi ini sangat berguna untuk menelaah dan menyimpulkan ketercapaian pemahaman peserta atas materimateri bahasa Arab yang disampaikan.
3. Wawancara

Wawancara merupakan upaya untuk menguatkan antara praktek dan tujuan dari pelatihan yang dilaksanakan. Wawancara ini ditujukan langsung kepada penemu Metode Terjemah Al-Qur'an Al-Huda, Ust. Ahmad Huseno, S.S.

\section{Teknik Analisis dan Pengolahan Data}

Langkah-langkah dalam menganalisis kegiatan ini adalah diawali dengan studi lapangan dengan memperhatikan dengan seksama setiap langkah yang dilakukan, kemudian dilanjutkan dengan mengidentifikasi pemahaman para peserta dari materi-materi yang diberikan, setelah itu proses identifikasi terhadap respon peserta pun dilakukan guna melihat hasil dan manfaat dari kegiatan ini.

\section{PEMBAHASAN DAN HASIL}

\section{Pengantar}

Kegiatan kerohanian Islam, saat ini sangat ramai diikuti oleh umat Islam se-Indonesia. Tidak hanya diminati anak-anak muda yang masih sekolah, melainkan para orang tua yang sudah tidak lagi memiliki kegiatan rutin ikut ramai mengikuti kegiatan ini. Program Metode Terjemah Al-Qur'n Al-Huda merupakan satu diantara sekian banyak program terjemah Al-Qur'an yang sangat ramai diikuti oleh para jamaah. Metode ini diminati banyak orang karena hasil dari para kader yang telah mengikuti pelatihan ini terbilang sukses dan sangat memadai.

\section{Profil Program Terjemah Al-Qur'an Al-Huda}

\section{Penemu Metode Al-Huda}

Nama : Ustadz Ahmad Huseno. S.S.

Ttl : Ogan Komerung Ulu, Palembang, 5 Maret 1977

Riwayat Pendididkan:

- Pesantren Babussalam, Madium-Jawa Timur

- Pesantren Modern Darussalam Gontor

- UIN Yogyakarta

Tanggal Penemuan Metode: 9 April 2003

Karya:

1. 60 Hari Bisa Menerjemahkan Al-Qur’an Sendiri: Panduan Belajar Bahasa Arab Metode Al-Huda (2014)

2. 20 Hari Bisa Paham Al-qur'an dengan Tafsirnya Metode 3 in 1 (2016) 
Tujuan Program Terjemah Al-Qur'an Al-Huda

Tujuan Program terjemah Al-Qur'an adalah agar umat muslim Indonesia mampu memahami teks AlQur'an, sehingga al-Qur'an yang merupakan kitab suci umat Islam dapat dijadikan sebagai petunjuk bagi kehidupan.

\section{Materi-materi}

Pada hari pertama program ini dilakukan, instruktur mengenalkan terlebih dahulu tujuan dan materimateri yang akan dibahas. Lebih dalam lagi, instruktur menjelaskan secara detail, apa itu metode Al-Huda dengan segala target dan harapan yang akan dicapai. Adapun materi-materi bahasa Arab dasar yang diajarkan pada pelatihan ini adalah sebagai berikut:

Hari ke-1 : Mengartikan

Hari ke-2 : : Pembagian Jenis Kata

Hari ke-3 : : Pembagian Jenis Isim

Hari ke-4 : Pembagian satuan Jumlah Isim

Hari ke-5 : Pembagian Fi'il

Hari ke-6 : Kata Kerja Aktif dan Pasif

Hari ke-7 : Ciri-ciri Fi'il Madhi, Mudhari' dan Amr

Hari ke-8 : Perubahan Kata

Hari ke-9 : Pola perubahan kata keseluruhan

Hari ke-10 : Contoh perubahan kata keseluruhan

Hari ke-11 : Asal usul Kata Kerja

Hari ke-12 : Mujarrad

Hari ke-13 : Mujarrad ke Mazid

Hari ke-14 : Mazid Empat Huruf

Hari ke-15 : Mazid Lima Huruf

Hari ke-16 : Mazid Enam Huruf

Hari ke-17 : Pola Perubahan Kata Mujarrad

Hari ke-18 : Pola Perubahan Kata Mazid Empat Huruf

Hari ke-19 : Pola Perubahan Kata Mazid Lima Huruf

Hari ke-20 : Pola Perubahan Kata Mazid Enam Huruf

Hari ke-21 : Jumlah (Kalimat)

Hari ke-22 : Macam-macam Khabar

Hari ke-23 : Kana, Isim Kana, Khabar Kana

Hari ke-24 : Inna, Isim Inna, Khabar Inna

Hari ke-25 : Fa'il dan Na'ibul Fa'il

Hari ke-26 : Fi'il, Fa'il, Maf'ul

Hari ke-27 : Mudhaf Ilaih

Hari ke-28 : Munada

Hari ke-29 : Tawabi'

Hari ke-30 : Kesimpulan Kedudukan Isim

Hari ke-31 : Perubahan Bentuk Akhir Kata

Hari ke-32 : Status dan Tanda

Hari ke-33 : Status Marfu' dan Kedudukan Isim

Hari ke-34 : Status Manshub dan Kedudukan Isim
Hari ke-35 : Status Majrur dan Kedudukan Isim

Hari ke-36 : Kesimpulan Status dan Kedudukan Isim

Hari ke-37 : Status Marfu' dan Tanda

Hari ke-38 : Status Manshub dan Tanda

Hari ke-39 : Status Majrur dan Tanda

Hari ke-40 : Kesimpulan Tanda-tanda I'rab (Isim)

Hari ke-41 : Status Marfu' dan Tanda Fi'il Mu'rab

Hari ke-42 : Status Manshub dan Tanda Fi'il Mu'rab

Hari ke-43 : Status Majzum dan Tanda Fi'il Mu'rab

Hari ke-44 : Kesimpulan Tanda-tanda I'rab (Fi'il)

Hari ke-45 : Isim Istifham

Hari ke-46 : Isim Syarath

Hari ke-47 : Isim Zharaf

Hari ke-48 : Isim Isyarah

Hari ke-49 : Isim Maushul

Hari ke-50 : Isim Dhamir

Hari ke-51 : Tanda Isim Mabni, Tempat Status \& Kedudukan

Hari ke-52 : Fi'il-fi'il Mabni (Fi'il Madhi)

Hari ke-53 : Fi'il-fi'il Mabni (Fi'il Mudhari)

Hari ke-54 : Fi'il-fi'il Mabni (Fi'il Amr)

Hari ke-55 : Harf-harf Mabni

Hari ke-56 : Harf Inna dan Nida'

Hari ke-57 : Harf Jarr

Hari ke-58 : Harf Nashab

Hari ke-59 : Harf Jazm

Hari ke-60 : Meng-i'rab

\section{Contoh Praktek Penerjemahan}

Contoh yang akan penulis lampirkan pada laporan ini hanya contoh pada dua materi di awal pertemuan saja. Dengan tujuan dapat memberikan sedikit gambaran terkait pelaksanaan program kegiatan ini.

Pada pelajaran pertama ini yang dipelajari adalah memilah dan mengartikan setiap kata dari penggalan kalimat dalam al-Qur'an. Materi pembahasannya baru terbatas pada pengenalan ciri pelaku (subjek).

$$
\text { الْحَمْدُ للَّهِ رَبِّ الْعَالَمِيْنَ }
$$

\begin{tabular}{|c|c|c|c|c|}
\hline الْعَالَمِيْنَ & رَبّْ & لِّهَ & J & الْحَمْدُ \\
\hline Semesta Alam & Tuhan & Allah & Bagi & Segala Puji \\
\hline
\end{tabular}




\section{Analisis dan Hasil}

Dari pelatihan yang telah berlangsung selama beberapa bulan ini, penulis berhasil mengidentifikasi sekaligus menganalisis segala hal yang berkaitan dalam pelaksanaan kegiatan ini dan lebih fokus mengaitkannya dengan teori-teori dan kebutuhan pembelajaran dasar bahasa Arab.

\section{Analisis}

Dari beberapa pertemuan yang penulis lakukan dalam rangka pengabdian kepada masyarakat ini, banyak hal yang membuat penulis takjub dari konsistensi dan hasil para peserta. Dimana mereka sangat antusias dan cepat menangkap materi yang diberikan. Walaupun, dapat dikatakan mayoritas peserta pelatihan ini adalah 'Ibu-ibu yang usianya diatas 40 tahun, bahkan diantara mereka adalah para purna bakti' yang memang sengaja mengisi kegiatan di masa purna baktinya. Terlihat di wajah mereka (para peserta) sangat bersemangat demi dapat memahami Al-Qur'an.

Dalam pelatihan ini, penulis sangat kagum kepada para peserta yang dengan spontan dapat menyebutkan dan memahami posisi kata-kata dalam Al-Qur'an dengan benar, sehingga dapat menerjemahkan ayat-ayat Al-Qur'an, walaupun hanya sebatas terjemahan kata.

Salah satu hal yang dianggap sulit dalam mempelajari bahasa Arab adalah, pada saat menentukan 'I'rab' posisi kata tersebut dan kemudian menguraikan dengan penjelasan yang lengkap, baik dari segi harakat, maupun kedudukan. Namun, lagi-lagi harus penulis katakan, sepertinya hal di atas tidak mengurangi antusiasme para peserta untuk terus memahami dan mendalami isi Al-Qur'an.

Namun, dalam keterkaitannya dengan teori-teori berbasis bahasa Arab, penulis menemukan beberapa evaluasi dalam pelatihan ini, yang apabila dapat diperbaiki sesuai dengan solusi yang penulis arahkan, pelatihan ini akan menjadi lebih sempurna.

\section{Solusi dan Hasil}

Setelah melangsungkan beberapa kali kegiatan, penulis menyimpulkan beberapa hasil yang didapat, yaitu: (1) para peserta dapat memahami kaidah Bahasa Arab dasar; (2) peserta sedikit demi sedikit mulai dapat mempraktekkan terjemah dari beberapa ayat al-Qur'an.
Pengabdian kepada masyarakat berbasis penelitian yang penulis lakukan ini, tidak semata-mata hanya untuk menambah wawasan dan informasi terkait pelatihan yang dilakukan. Namun, lebih jauh dari itu, penulis sangat berharap dapat memberikan pengaruh postif yang besar terhadap proses belajar mengajar pada pelatihan tersebut. Terlebih hal-hal yang berkaitan langsung dengan bahasa Arab dasar. Tanpa mengurangi rasa kagum atas hasil yang telah dicapai oleh para peserta program terjemah $\mathrm{Al}$ Qur'an Al-Huda ini, penulis hanya ingin memberikan beberapa masukan agar hasil dari pelatihan ini dapat lebih maksimal.

Sebelum penulis mengutarakan masukan-masukan pada pelatihan ini, pada pertemuan sebelumnya, penulis pun sudah mengungkapkan banyak hal postif dari ide brilian dang penemu metode $\mathrm{Al}$ Qur'an Al-Huda ini, Ustadz Ahmad Huseno, S.S. diantaranya adalah:

1. Karena materi yang diberikan didesain sesimple mungkin, maka pemahaman dan tanggapan dari para peserta pun sangat postif. Peserta dengan sangat mudah memahami teori-teori dasar bahasa Arab. Hal ini terlihat setelah lima sampai sepuluh kali pertemuan. Dimana para peserta sudah dapat menentukan posisi-posisi kata pada ayat-ayat yang dipelajari dengan baik dan cukup detail.

2. Selain materi-materi bahasa Arab yang diajarakan secara tematik, ayat-ayat yang diberikan juga cenderung tematik. Hal ini bertujuan agar peserta dapat merangkum dari pemahaman kisah-kisah yang kemudian dijabarkan dengan bahasa Indonesia yang tepat agar mudah dipahami.

3. Setiap pertemuan hanya membahas teori-teori sederhana atau dirancang sesederhana mungkin, yang efeknya dapat mudah diterima dan dicerna oleh peserta. Baik teori, maupun praktek.

Adapun hal-hal yang menjadi masukan penulis pada pelatihan ini, adalah sebagai berikut:

1. Tidak tersedianya fasilitas kamus yang memadai. Karena, dalam proses menerjemahkan apapun, kita sebagai non penutur, sudah tentu sangat membutuhkan kamus. Ketersediaan kamus menjadi hal yang sangat primer.

2. Penerejemahan yang dilakukan pada pelatihan ini hanya sebatas terjemah harfiah. Dimana para peserta menerjemahkan setiap kata dalam ayat-ayat Al-Qur'an, tidak serta merta 
memperhatikan konteks makna ataupun kisah yang terkandung dalam ayat tersebut.

Dalam hal upaya pengembangan pada program pelatihan ini, penulis memberikan beberapa masukan dari penilaian yang penulis ungkapkan di atas dengan harapan kegiatan ini akan semakin memiliki nilai lebih dan dapat meningkatkan kualitas dan kuantitas peserta. Adapun solusi yang telah penulis coba dalam menyikapi dua hal masukan tersebut di atas adalah sebagai berikut :

1. Upaya pengadaan kamus saku yang cukup memadai dan mudah digunakan oleh para peserta yang cenderung 'awam' dalam menggunakan kamus.

2. Pengenalan atau penjelasan secara singkat akan kisah atau isi dari ayat yang akan dikupas pada materi tersebut. Sehingga peserta betulbetul memahami maknanya secara dalam.

\section{KESIMPULAN DAN SARAN}

\section{Kesimpulan}

Berdasarkan dari hasil olah data dan studi lapangan yang telah dilakukan, penulis menyimpulkan beberapa hal, yaitu :

1. Pelatihan Program Terjemah Al-Qur'an dengan Metode Al-Huda sampai saat ini sangat diminati oleh ibu-ibu daerah Jabodetabek. Karena merupakan suatu kebanggaan bagi umat Islam jika mampu menerjemahkan Al-Qur'an secara umum.

2. Solusi yang penulis coba terapkan, bukanlah tolak ukur utama yang menentukan kesuksesan dan kemajuan pelatihan ini. Namun, apa yang diberikan itu semata-mata dilatarbelakangi oleh wawasan yang dimiliki penulis dalam hal bahasa Arab.

\begin{abstract}
Saran
Pengabdian kepada masyarakat berbasis penelitian yang dilaksanakan dalam kurun waktu kurang lebih delapan bulan ini, tentu masih jauh target yang diharapkan, khususnya untuk pengembangan bahasa Arab.

Di mata masyarakat muslim daerah Jabodetabek saat ini, kegiatan ini sangat menarik perhatian, khususnya kalangan ibu-ibu. Adapun saran penulis tentang kegiatan ini adalah upaya pengembangan baik dari segi kualitas materi maupun media pendukung. Agar target dan tujuannya dapat lebih memuaskan.
\end{abstract}

\section{DAFTAR PUSTAKA}

[1] Catford, J.C, 1965, A Linguistic Theory of Translation, Oxford Univ. Press

[2] Hoed, Benny Hodeoro, 2003

[3] Huseno, Ustadz Ahmad, 2016, 60 Hari Bisa Menerjemahkan Al-Qur'an Sendiri, Khazanah Pustaka Islam

[4] Kamus Besar Bahasa Indonesia, 2002, Balai Pustaka

[5] http//www.artikata.com

[6] jelajah.internet.com 